\title{
The Mediating Role of Employee Satisfaction on the Effect of Competencies and Work Environment on Employee Performance: On the Pandemic Covid 19 Era
}

\author{
Mahmudah Enny Widyaningrum \\ Faculty of Economics and Business Univeristy of Bhayangkara Surabaya
}

\begin{abstract}
The objective of this study is to examine the effect if competencies and work environment on employee performance with employee satisfaction as an intervening variable. This paper is work during the Covid 19 Pandemic era. The research used primary data and census sampling with number of sample 150 employees of CV Sapta Bona Artha company. The result shows that competencies and work environment has a positive effect on employee satisfaction and employee performance. Also, employee satisfaction shows a positive effect on employee performance. The research also found that employee satisfaction mediates the effect of competencies and work environment on employee performance. It is recommended that employee satisfaction is an important role to improve the employee performance. New normal conditions may cause uncertainty on the employee on improving their performance. Therefore, the company will need to formalize the best strategy for improving employee behavior to make the target and the objective of a company successfully achieved.
\end{abstract}

Keywords: Competencies, work environment, Job Satisfaction, Employee Performance

DOI: $10.7176 / \mathrm{EJBM} / 12-36-04$

Publication date: December $31^{\text {st }} 2020$

\section{INTRODUCTION}

HR management should be integrated with organizational management and organizational strategic planning processes more effectively, to achieve better performance. But, during the Covid 19 pandemic, the effort in achieving the performance is getting slow and even stuck for some companies in the world, including Indonesia (Puspasari, 2020). These conditions affect CV Sapta Bona company unable to improve the employee performance. The pandemic covid 19 has impact of fear and doubt for so many peoples, including employees, even though their responsibility and workloads that must be resolved are kneaded to meet the results of achieving high performance. Performance is a result of work achieved by a person in carrying out the tasks assigned to him for his skills, experience, seriousness and time (Hasibuan, 2017). According to Setiyawan and Waridin (2006), a person's work can be assessed in terms of quality and quantity according to the work standards in the organization. The work results achieved by a person both in quality and quantity within a certain period time are suitable for the responsibilities and workload assigned to him (Mangkunegara, 2016). Performance is used as a measurement of achievement of employee work results, and employee success is as a contribution to support and to achieve the organizational goals. The better the work results achieved, the better the employee job satisfaction is obtained. High employee satisfaction at work can result in job performance (Rachman, 2017).

Employees development program during The Pandemic and Post-Pandemic may not become like before the era of Covid-19 pandemic, employees are less focused on improving their performance. Many employees have been working from home. Therefore the role of the organization on employees is needed to encourage competitive advantage in producing job performance. The organizational support and job performance can be strengthened when employees feel the satisfaction with the job (Sharma and Biswakarma, 2020). Employee satisfaction can be described as how satisfied an employee with his job position (Moyes et al., 2008). According to Robbins and Judge (2017), job satisfaction is a general attitude of an individual towards the job, a person with a high level of job satisfaction shows a positive attitude towards the job. People who are dissatisfied with their work tend to display negative attitudes towards the job. So that the problem between satisfaction and dissatisfaction in the organization will be an obstacle in achieving the work performance of employees in the CV Sapta Bona Artha environment.

The Organizational support with competencies perceived is correlated with job satisfaction and work performance. It shows that job satisfaction mediates the effect of organizational support perceived on job performance. Competence is described as the ability to carry out tasks, the ability to integrate knowledge, skills, attitudes or personal values, and the ability to build knowledge and skills based on the knowledge and learning that is carried out (Tannady, 2017 ). According to Campion et al., (2011) that competitive advantage in any organization is obtained by retaining competent employees as the main resource. Cummings and Worley (2011) found that new knowledge, skills, and behaviors are required from employees because of frequent organizational changes. Competence was not a new concept at its time but became the latest organizational practice due to certain developments in that direction (Patil, 2014). This is what makes the organization often make changes to overcome 
uncertain work environment conditions. Due to the increase in the quality and competence of employees is a top priority in the organization. the importance of a good work environment is to maximize the level of job satisfaction (Raziqa and Maulabakhsha, 2014), and various factors in the work environment such as wages, working hours, autonomy given to employees, and the establishment of an organization in employee communication affect job satisfaction (Lane et.al., 2010). The importance of a good work environment to maximize the level of job satisfaction (Raziqa and Maulabakhsh, 2015). Agbozo et al. (2017) that the environment has a significant influence on employee satisfaction, and always emphasizes the need for management to improve the work environment of employees in improving their work results. This shows evidence that environmental conditions support employee work activities to produce job outcomes (Rachman, 2020). Hence, the research problems related that employee job performance often changes. Therefore, the research question of this research can be identified as follows:

1. Does competency affect employee job satisfaction?

2. Does the work environment affect employee job satisfaction?

3. Do competencies affect employee performance?

4. Does the work environment affect employee performance?

5. Does job satisfaction affect employee performance?

6. Does Job satisfaction mediate on the effect of competencies on employee performance?

7. Does Job Satisfaction mediate the effect of the work environment on employee performance?

Based on the formulation of the problem proposed in this research is then compiled with the conceptual model as in the figure below;

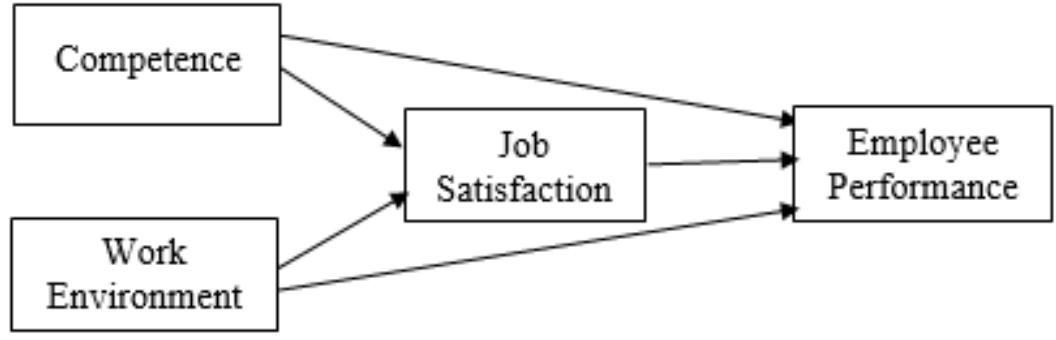

Figure 1. The Model Conceptual Framework

\section{LITERATURE REVIEW AND HYPOTHESIS DEVELOPMENT}

\section{Competencies}

Competency is an action taken by a person to improve intellectual thinking skills, carry out tasks based on knowledge, have work skills, and have a confident attitude/behavior to produce jobs (Rachman, 2012). Competencies consist of task skills, task management skills, contingency management skills, job role skills, and skill transfer (Ardianto et al., 2015). According to Francis (2015), Rahardjo (2014), Sriekaningsih (2015), Spencer and Spencer (1993), Hutapea and Thoha (2008) found that the competencies used to improve employee work in organizations consist of knowledge, abilities, and work attitudes. Previous research shows that competencies have a positive effect on improving employee work results because competence can change employee personality attitudes in understanding organizational goals (Suarmiati et al., 2018).

\section{Work Environment}

The work environment is an important factor in improving employee performance.

The work environment is everything that is around the workers and which can affect them in carrying out the tasks as assigned (Nitisemito, 2008). However, if the work environment is not good, it can pressure employees to take more time, and it does not support the acquisition of an efficient work system design (Sedarmayanti, 2011). According to Moekijat (2006), a good and comfortable company work environment can motivate employees to increase high work results, also, that good working conditions can reduce boredom and fatigue at work, so that it can improve employee performance properly. A supportive work environment helps workers to perform normal tasks effectively. Work environment creates the best use of their knowledge, skills and competencies as well as available resources to provide high-quality services (Leshabari et al., 2008), whereas Abualrub et al. (2016), Agbozo et al. (2017), Ayamolowo (2013), Bojadjiev et al. (2015) found that work environment factors have a positive effect on the dimensions of job satisfaction according to the conditions in which employees perform work activities. Therefore, the importance of a good work environment is to maximize the level of job satisfaction. This can benefit society by encouraging people to contribute more to their work and can assist them in their personal growth and development. Therefore, organizations need to motivate and give satisfaction to their employees to work hard to achieve organizational goals and objectives (Raziqa and Maulabakhsha, 2015). 


\section{Job Satisfaction}

Job satisfaction is the emotional feelings of employees about their job. Job satisfaction could be on their job in general or their attitude towards certain features, such as co-workers, salary, or working conditions (Lu and Barriball, 2005). Also, people's work results can meet or exceed expectations in determining the level of job satisfaction. Good and effective supervision by management will increase the level of employee satisfaction. Meanwhile, poor communication skills will increase the level of dissatisfaction among employees (Schroffel, 1999). Therefore, situational influences are important on job satisfaction, it might be related to the job itself and/ or it is the most important personality type for predicting the core of self-assessment on job satisfaction. According to Catillo \& Cano (2004) that the level of job satisfaction among faculty members in tertiary institutions shows that proper attention is given to the interpersonal relationships, recognition and supervision will increase the level of job satisfaction. Bakotic \& Babic (2013) found that for workers who work in difficult working conditions, are not. Therefore, working conditions is an important factor. Previous research also found that other personality behaviors, such as extraversion and thoroughness is also affected job satisfaction of employees (Jugde and Mount, 2002). This will make them equally satisfied with those who work in normal working conditions, and vice versa, overall performance will increase, and job satisfaction is a general attitude of individual work for people who have differences in the rewards received by employees with rewards that are believed to be acceptable (Robbins, 2015).

\section{Performance}

Employee performance can be known after people demonstrate their ability to carry out their duties and responsibilities. According to Sinambela, et al., (2016) employee performance is defined as the ability of employees to perform certain skills. Mangkunegara (2017) performance as a result of work achieved by employees in carrying out their duties both in quality and quantity with responsibility, while employee performance appraisal is based on assumptions. The assessment of employee performance is based on the assumptions (Mangkunegara, 2017) including quantity of work, quality of work, and timeliness of work.

Base on the above empirical research, this research has developed the followings research hypothesis:

H1: Competencies affect employee job satisfaction

$\mathrm{H} 2$ : Work environment affect employee job satisfaction

H3: Competencies affect employee performance

H4: Work environment affect employee performance

H5: Job satisfaction affects employee performance

H6: Job satisfaction mediate on the effect of competencies on employee performance

H7: Job Satisfaction mediate the effect of the work environment on employee performance

\section{Research Method \\ Research Design}

The type of research used is a development model, the research is to examine the relationship between variables with sampling techniques as a tool for the data analysis process. This research design explains the details of important procedures to obtain the information needed to compile and / or solve research problems, and is a type of explanatory research (Rachman, 2018)

\section{Sample}

The sample of this research used 150 employees at CV Sapta Bona Artha in the district. Tulangan Sidoarjo Regency. While the sampling technique used saturated samples, because the population and samples for employees in this study were heterogeneous and limited in the number of populations, so the sampling technique used was saturated samples (Rachman, 2018). This research is used path analysis. The instrument testing research is used by determining the validity magnitude above 0.30 and the reliability measurement is above 0.60 ; and testing between variables using the t-test (Rachman, 2019).

\section{RESULT AND DISCUSSION}

\section{Validity Analysis}

The problem of instrument validity (questionnaire) will show whether the instrument (questionnaire) can measure the object, as in the table below; 
Table 1. Validity Instrument Testing Result

\begin{tabular}{|c|c|c|c|}
\hline Item Statement & $\begin{array}{c}\text { Correlated Item-Total } \\
\text { Correlation }\end{array}$ & $\begin{array}{c}\text { Critical Value } \\
\alpha=0,30\end{array}$ & Conclusion \\
\hline \multicolumn{4}{|c|}{ Competencies $\left(\mathrm{X}_{1}\right)$} \\
\hline $\mathrm{X} 1.1$ & 0,854 & & Valid \\
\hline $\mathrm{X} 1.2$ & 0,818 & 0.30 & Valid \\
\hline $\mathrm{X} 1.3$ & 0,759 & & Valid \\
\hline X1.4 & 0,521 & & Valid \\
\hline \multicolumn{4}{|c|}{ Work Environment $\left(\mathrm{X}_{2}\right)$} \\
\hline $\mathrm{X} 2.1$ & 0,809 & & Valid \\
\hline $\mathrm{X} 2.2$ & 0,552 & 0.30 & Valid \\
\hline $\mathrm{X} 2.3$ & 0,359 & & Valid \\
\hline $\mathrm{X} 2.4$ & 0,793 & & Valid \\
\hline \multicolumn{4}{|c|}{ Job Satisfaction $\left(\mathrm{X}_{3}\right)$} \\
\hline X3.1 & 0,830 & & Valid \\
\hline $\mathrm{X} 3.2$ & 0,504 & 0.30 & Valid \\
\hline $\mathrm{X} 3.3$ & 0,479 & & Valid \\
\hline X3.4 & 0,868 & & Valid \\
\hline \multicolumn{4}{|c|}{ Employee Performance (Y) } \\
\hline $\mathrm{Y} 1$ & 0,845 & & Valid \\
\hline $\mathrm{Y} 2$ & 0,546 & 0.30 & Valid \\
\hline Y3 & 0,765 & & Valid \\
\hline
\end{tabular}

Source: processed by researcher (2020)

Table 1 above shows that the overall variable indicators used in the study have a Correlated Item-Total Correlation coefficient value above $0.30(>0.30)$. It means that all indicator statement items used to measure the variable are valid and accepted.

\section{Reliability Analysis}

Reliability is an index that shows the extent to which a measuring instrument is used twice to measure the same symptoms, as shown in table 2 below.

Table 2. Reliability Analysis Result

\begin{tabular}{|l|l|l|l|}
\hline Variable/ Indicator & Alpha Cronbach & Critical value & Note \\
\hline Competencies (X1) & 0,820 & & Reliable \\
\hline Work Environment (X2) & 0,802 & 0.60 & Reliable \\
\hline Job Satisfaction (X3) & 0,830 & & Reliable \\
\hline Employee Performance (Y) & 0,842 & & Reliable \\
\hline
\end{tabular}

Source: processed by researcher (2020)

Based on above result, it shows that the independent variables consisting of competencies (X1), work environment (X2) and job satisfaction (X3), and the dependent variable employee performance (Y) each have a Cronbach's Alpha value $>0.6$. This means that all variables, namely competence, work environment, job satisfaction and employee performance are declared reliable, and the results of this analysis can be continued.

\section{Path Analysis}

This research using path analysis to see the influence of competence, and work environment on job satisfaction and employee performance in CV Sapta Bona Artha can be shown as the results of the path analysis as in the figure and table below.

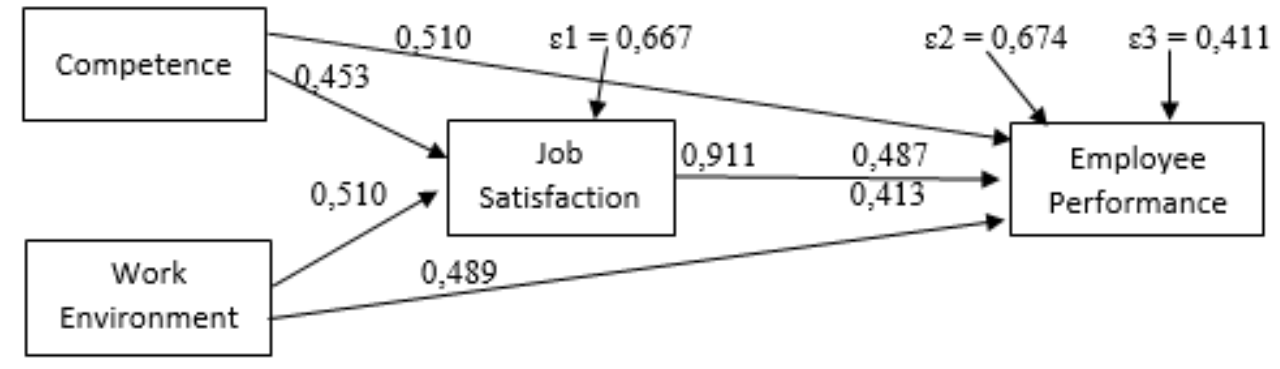

Figure 2. Path Analysis Model 
The results of the path analysis model it can be assumed based on the direction of the lines of influence between the variables analyzed so that can clarify as summarized the results of which are shown in table 3 below;

Table 3 Path Analysis result

\begin{tabular}{|c|c|c|c|c|c|}
\hline Variable & $\begin{array}{l}\text { Direct } \\
\text { Effect }\end{array}$ & $\begin{array}{c}\text { Indirect } \\
\text { Effect }\end{array}$ & $\begin{array}{l}\text { Significance } \\
\quad \text { (Sig.) }\end{array}$ & $\begin{array}{l}\text { Conclusion } \\
(\text { Sig. }<0,05)\end{array}$ & $\mathbf{R}^{2}$ \\
\hline $\begin{array}{l}\text { 1. Competencies }\left(\mathrm{X}_{1}\right) \rightarrow \text { Work } \\
\text { Environment }(\mathrm{X} 2)(\mathrm{H} 1)\end{array}$ & 0,535 & & 0,000 & $\begin{array}{l}\text { Significant/ H1 } \\
\text { Accepted }\end{array}$ & 0,555 \\
\hline $\begin{array}{l}\text { 2. Work Environment }\left(\mathrm{X}_{2}\right) \rightarrow \text { Job } \\
\text { Satisfaction }(\mathrm{X} 3)(\mathrm{H} 2)\end{array}$ & 0,453 & & 0,001 & $\begin{array}{l}\text { Significant/ H2 } \\
\text { Accepted }\end{array}$ & \\
\hline $\begin{array}{l}\text { 3. Competencies }\left(\mathrm{X}_{1}\right) \rightarrow \text { Employee } \\
\text { Performance }(\mathrm{Y})(\mathrm{H} 3)\end{array}$ & 0,510 & & 0,000 & $\begin{array}{l}\text { Significant/ H3 } \\
\text { Accepted }\end{array}$ & 0,546 \\
\hline $\begin{array}{l}\text { 4. Work Environment }\left(\mathrm{X}_{2}\right) \rightarrow \\
\text { Employee Performance }(\mathrm{H} 4)\end{array}$ & 0,489 & & 0,000 & $\begin{array}{l}\text { Significant/ H4 } \\
\text { Accepted }\end{array}$ & \\
\hline $\begin{array}{l}\text { 5. Job Satisfaction }(\mathrm{X} 3) \rightarrow \text { Employee } \\
\text { Performance }(\mathrm{Y})(\mathrm{H} 5)\end{array}$ & 0,911 & & 0,000 & $\begin{array}{l}\text { Significant/ H5 } \\
\text { Accepted }\end{array}$ & 0,831 \\
\hline $\begin{array}{l}\text { 6. Competencies } \rightarrow \text { Job Satisfaction } \\
(\mathrm{X} 3) \rightarrow \text { Employee Performance (Y) } \\
(\mathrm{H} 6)\end{array}$ & & 0,487 & & $\begin{array}{l}\text { Significant/ H6 } \\
\text { Accepted }\end{array}$ & \\
\hline $\begin{array}{l}\text { 7. Work Environment }(\mathrm{X} 2) \rightarrow \text { Job } \\
\text { Satisfaction }(\mathrm{X} 3) \rightarrow \text { Employee } \\
\text { Performance }(\mathrm{Y})(\mathrm{H} 7) \\
\end{array}$ & & 0,413 & & $\begin{array}{l}\text { Significant/ H7 } \\
\text { Accepted }\end{array}$ & \\
\hline
\end{tabular}

Source: processed by researcher (2020)

Base on table 3 shows the path analysis are as follows:

a) Competencies (X1) has a positive and significant effect on job satisfaction (X3), with a path coefficient of 0.535 and sig. 0,000. It means that the competencies are increased in a positive direction. Because the better the respondent's (employee's) assessment of the competencies provided by the leaders, the higher the employee's job satisfaction is shown by the employee. Although the encouragement for employees in the new Normal during the Covid-19 pandemic still has the potential to produce higher job satisfaction, therefore that employees indirectly still survive and able to improve their work results.

b) The work environment (X2) has a significant effect on job satisfaction (X3), with a path coefficient of 0.453 and sig. 0.001. This means that the work environment is increased in a positive direction. Because the better the respondent's (employee's) assessment of the work environment, the higher the employee's job satisfaction in doing his job in the New Normal era during the Covid-19 Pandemic. Because employees have considered and introduced other work models they have seen during the Covid-19 pandemic, employees can change their attitudes and behavior in achieving organizational goals.

c) The competencies variable (X1) has a positive and significant effect on employee performance (Y), with a path coefficient of 0.510 and sig. 0,000. It means that the competencies are increased in a positive direction. Because the better the employee's assessment of the competencies provided by the organization, the higher the performance that the employees produce in supporting organizational goals. Opportunities and employee support in being competent to have an important role even in the era of the Covid-19 Pandemic because of limitations at the workplace are still imposed by the organization, so the ac

d) The work environment variable (X2) has a positive and significant effect on employee performance (Y), with a path coefficient of 0.489 , and sig. 0,000 . It means that the work environment is increased in a positive direction. Because the better the respondent's (employee) assessment of the work environment with pleasant conditions and guaranteed security, the higher the employee's enthusiasm for carrying out activities and encourages an increase in the resulting work performance. The organization realizes that the condition of the Covid-19 pandemic, the organization prefers to offer to work in an environment where the reduction of the number of employees is required. It may cause that the performance produced by employees is not optimal as targeted by the organization. So that the work results of the employee are not fully achieved compared to the era before Covid-19.

e) Job satisfaction (X3) has a positive and significant effect on employee performance (Y), with a path coefficient value of 0.911 and sig. 0,000 . This means that the job satisfaction is increased in a more positive direction. These results indicate that the employee's job satisfaction that he responded can provide satisfaction to the organization. Therefore, it has an impact on improving job performance according to organizational 
expectations. This also indicates that employees are aware that the Covid-19 Pandemic condition can produce high performance because employees effectively take actions to maintain and improve physical health in improving the emotional well-being of employees at work.

f) The meaning of direct and indirect effect calculation is to determine the function or role of the intervening variable of job satisfaction (X3). The results of the analysis of the indirect effect of competence (X1) on employee performance (Y) through job satisfaction have a positive impact, it is indicated by a coefficient value of 0.487 . So It will be able to bring the significant changes in employee work activities because of the desire of company leaders that the ability of employees competencies can produce high satisfaction in supporting the achievement of job performance indirectly. Due to the caution of employees in their activities in the New Normal era during the Covid-19 pandemic, they can maintain high-risk conditions with little work time and can produce a high performance to achieve organizational goals.

g) The meaning of direct and indirect effect calculation is to determine the function or role of the intervening variable in this study is job satisfaction (X3). The results of the analysis of the indirect effect of the work environment on employee performance through job satisfaction have a positive impact because it is indicated by a coefficient value of 0.413 . This positive influence shows that the company's leaders have responded to the desire of employees to facilitate better employee working conditions during their activities so that they can bring about changes to increase their work results.

\section{CONCLUSION}

The results of the discussion analysis can be concluded, namely:

a) Competencies has a positive and significant effect on employee job satisfaction. These results inform that the competencies of employees can produce job satisfaction that can satisfy company goals.

b) The work environment has a significant positive effect on employee job satisfaction. These results indicate that expectations in providing high job satisfaction in producing jobs have been supported by a comfortable work environment to be used in work activities so that they can bring significant changes to employee job satisfaction.

c) Competencies has a positive and significant impact on employee performance. This means that employees' competencies can produce jobs that can meet company expectations, supported by several indicators of ability, skill knowledge and work behavior to improve their performance.

d) The work environment has significant effect on employee performance. It shows that the comfort of employees in carrying out work activities can produce high performance according to company expectations.

e) Job satisfaction has a positive and significant effect on employee performance, It indicates that the higher the employee's job satisfaction, the higher the employee's work is achieved by the support of organizational goals.

f) Indirect influence of employee competencies performance through job satisfaction has a positive impact. This shows that employees can bring significant changes in their work activities so that the desire of company leaders indirectly supports high work results.

g) The indirect effect of the work environment on employee performance through job satisfaction has a positive impact. It shows that the company leaders have responded to the desire of employees to further facilitate the conditions of employee work comfort during their activities so that they can increase their work results following organizational goals

\section{RECOMMENDATION}

From the concluded research results can be used as a further consideration by the management of CV Sapta Bona Artha Sidoarjo, because competence has a good influence in improving employee performance.At least the skills or skills that employees have can be improved by going through various trainings according to their abilities and knowledge. The higher the management's attention on employees, the higher the management can change the competence of employees to be more accomplished even in covid-19 conditions. This has been supported by a comfortable, calm and satisfying work environment in producing a job.In addition, the company remains committed to prioritizing employee health protocols because employee job satisfaction during the Covid-19 pandemic can still change employee performance, as long as management can study employees' work activities to more potentially produce that job.Because the positive influence through employee job satisfaction can produce high performance in accordance with the company's expectations.

\section{REFERENCES}

Abualrub, Raeda Fawzi, Fadi El-Jardali, Diana Jamal, NawzatAbu Al-RubRN. (2016), Exploring the Relationship between Work Environment, Job satisfaction, and Intent to Stay of Jordanian Nurses in Underserved areas. Applied Nursing Research. Volume 31, August 2016, Pages 19-23. DOI: 10.1016/j.apnr.2015.11.014. https://www.sciencedirect.com/science/article/pii/S0897189715002311.

Agbozo, George Kafui, Isaac Sakyi Owusu, Mabel A. Hoedoafia. (2017). Yaw Boateng Atakorah. The Effect of 
Work Environment on Job Satisfaction: Evidence from the Banking Sector in Ghana. Journal of Human Resource Management; 5(1): 12-18. ISSN: 2331-0707 (Print); ISSN: 2331-0715 (Online). http://www.sciencepublishinggroup.com/j/jhrm doi: 10.11648/j.jhrm.20170501.12

Ardianto, J.T., Effendi, M., \& Santoso, I. (2015). Penilaian Kinerja Karyawan Berdasarkan Kompetensi Dengan Analytic Network Proces (ANP) (Studi Kasus di Bagian Produksi PT Perkebunan Nusantara Xii Kebun Wonosari Malang). Jurnal Universitas Negeri https://docplayer.info/storage/56/38847283/38847283.pdf

Ayamolowo, Joseph, Sunday, Omolola Irinoye, Mayowa Antony Oladoyin. (2013). "Job Satisfaction and Work Environment of Primary Health Care Nurses in Ekiti State, Nigeria: an Exploratory Study". International Journal of Caring Science. Volume 6 Issue 3. Pp. (www.internationaljournalofcaringsciences.org, SeptemberDesember, 2013) http://journals.ums.ac.id/index.php/dayasaing/article/download/3777/2446

Bakotic, Danica \& Babicm Tomislav. (2013). Relationship between Working Conditions and Job Satisfaction: The Case of Croatian Shipbuilding Company. International Journal of Business and Social Science. Vol. 4 No. 2; February 2013. http://www.ijbssnet.com/journals/Vol_4_No_2_February_2013/22.pdf

Bojadjiev, Marjan, Miodraga Stefanovska, Ana Tomovska Misoska, Julijana Stojanovska. (2015). Perceived Work Environment And Job Satisfaction Among Public Administration Employees. The European Journal of Applied Economics -EJAE. 12(1): 10-18 ISSN 2406-2588 UDK: 331.101.32:35.07(497.7) DOI: 10.5937/EJAE12-8154. https://scindeks-clanci.ceon.rs/data/pdf/2406-2588/2015/2406-25881501010B.pdf

Campion, M. A., Fink, A. A., Ruggeberg, B. J., Carr, L., Phillips, G. M., \& Odman, R. B. (2011). Doing Competencies Well: Best Practices in Competency Modeling. Personnel Psychology, 64, 225-262. http://dx.doi.org/10.1111/j.1744-6570.2010.01207.xhttps://www.scirp.org/(S(vtj3fa45qm1 ean45vvffcz55)/reference.ID=1216320.

Castillo, J.X. and Cano, J. (2004). Factors Explaining Job Satisfaction among Faculty. Journal of Agricultural Education, $\quad 45, \quad 65-74 . \quad \mathrm{http}: / / d x . d o i . o r g / 10.5032 /$ jae.2004.03065. https://www.scirp.org/(S(i43dyn45teexjx455qlt3d2q))/ReferenceID=1813961.

Cummings, Thomas G. and Worley, Christopher. (2011). Organization Development \& Change. Canada: Nelson Education, Ltd.

Francis, Joshua David. (2015). The Effects of Competency on Job Satisfaction for Professional Counselors When Providing Court Testimony. Dissertations; Walden University. Dissertations and Doctoral Studies.580. https://scholarworks.waldenu.edu/dissertations/580.

Hasibuan, Malayu, S.P. (2007). Organisasi dan Motivasi. Jakarta: Bumi Aksara.

Hutapea, Parulian dan Nurianna Thoha. (2008). Kompetensi Plus. Jakarta, PT Gramedia Pustaka Utama.

Rahardjo, S. (2014). The Effect of Competency, Leadership and Work Environment Towards Motivation and Its Impact on The Performance of Teacher of Elementary School in Surakarta Ciity, Central Java, Indonesia. International Journal of Advanced Research in Management and Social Sciences. ISSN: 2278-6236. Vol. 3. No. 6. June 2014. https://www.scribd.com/document/390470410/7-pdf

Lane, K., Esser, J., Holte, B., \& Anne, M. M. (2010). A study of nurse faculty job satisfaction in community colleges in Florida. Teaching and Learning in Nursing. 5(1), 16-26.

Leshabari M, Muhondwa E, Mwangu M, Mbembati N. (2008). Motivation of Health care workers in Tanzania: case study of Muhimbili National Hospital. East African Journal of Public Health, 5 (1): 30-36. http://www.bioline.org.br/pdf?lp08008

Lu, H., While, A. E. and Barriball, K. L. (2005). Job Satisfaction Among Nurses: A Literature Review. International Journal of Nursing $\quad$ Studies, $4211-227$. https://doi.org/10.1016/j.ijnurstu.2004.09.003. https://www.scirp.org//ReferencesPapers.aspx?ReferenceID=2038461

Mangkunegara, Anwar, P. (2016). Manajemen Sumber Daya Manusia. Bandung: PT Remaja Rosdakarya.

Moekijat. (2006). Human Resources and Relationship Management in Organizations, Edition, Bandung: Penerbit Alumni.

Moyes , G.D., Stephen Owusu-Ansah Gouranga Ganguliet al., (2008). Factors Influencing the Level of Job Satisfaction of Hispanic Accounting Professionals: A Perceptual Survey. Journal of Business \& Economic Studies., Volume 12, No. 1, Spring 2006 https:/www.researchgate.net/publication/288596024

Nitisemito, Alex S. (2008). Personnel Management, Jakarta: Ghalia Indonesia

Patil, Sumeet R., Benjamin F. Arnold, Alicia L. Salvatore, Bertha Briceno, Sandipan Ganguly, John M. Colford Jr, Paul J. Gertler. (2014). The Effect of India's Total Sanitation Campaign on Defecation Behaviors and Child Health in Rural Madhya Pradesh: A Cluster Randomized Controlled Trial. PLOS Medicine. August 2014. Volume $11 \quad$ Issue 8. e1001709. https://doi.org/10.1371/journal.pmed.1001709 https://journals.plos.org/plosmedicine/article/file?id=10.1371/journal.pmed.1001709\&type=printable.

Puspasari, Rahayu. (2020). Pemerintah Waspada Dampak Pandemi Covid-19 Terhadap Ekonomi Indonesia. Siaran Pers. Kepala Biro Komunikasi dan Layanan Informasi Kementerian Keuangan Republik Indonesia, 
April, 17-21. https://www.kemenkeu.go.id/apbnkita/.

Rachman, Mochammad Munir. (2012). Pengaruh Kemampuan Intelektual, Pembelajaran Individual, Dan Internasl Locus Of Control Terhadap Kompetensi Dan Kinerja Dosen (Studi Prodi Manajemen Terakreditasi B Pada Universitas Swasta di Surabaya. Majalah Ekonomi (JEBA/ Jurnal Ekonomi dan Bisnis Airlangga) pISSN: 2338-2686; e-ISSN: 2597-4564. Tahun XXII (1) April $2012 . \quad \mathrm{https} / / / \mathrm{e}-$ journal.unair.ac.id/JEBA/article/download/4333/2968

Rachman, Mochammad Munir. (2017). The Influence of Work Culture on Job Satisfaction and Performance: A Study on the Employees of the Bank Jatim in Surabaya, East Java, Indonesia. European Journal of Business and Management. Vol.9, No.26. https://iiste.org/Journals/index.php/EJBM/article/view/38791/39892.

Rachman, Mochammad Munir. (2018). Metodologi Penelitian. Cetakan Kedua. Surabaya: Unipress, Universitas PGRI Adi Buana.

Rachman, Mochammad Munir. (2019). Aplikasi Komputer Statistik: Sebagai Pendekatan Untuk Analisis Data Statistik Dengan SPSS. Cetakan Ketiga. Surabaya: Unipress, Universitas PGRI Adi Buana.

Rachman, Mochammad Munir. (2020). The Influence of Transformational Leadership on the Performance of Employees with Motivation and Job Satisfaction as Intervening (A Study on the Office of the Department of Irrigation works in the District of Sidoarjo, Indonesia). European Journal of Business and Management. Vol.12, No. 14. https://iiste.org/Journals/index.php/EJBM/article/view/52872/54631.

Raziq, Abdul dan Maulabakhsha, Raheela. (2015). Impact of Working Environment on Job Satisfaction. Procedia Economics and Finance. 23, 717-725. https://doi.org/10.1016/S2212-5671(15)00524-9. https://www.sciencedirect.com/science/article/pii/S2212567115005249

Robbins, Stephen P. (2014). Organization Theory: Structure, Design, And Applications. New Jersey: Pearson Pentice-Hall Upper Saddle River, ISBN-13: 978-0136419457

Robbins, Stephen P. and Judge, Timothy. (2019). Organizational Behavior. USA. America: Pearson Education, Inc. ISBN 13: 978-0-13-472932-9.

Schroffel, Alan. (1999). How Does Clinical Supervision Affect Job Satisfaction? The Clinical Supervisor. Volume 18(2). https://brantfacs.ca/wp-content/uploads/2017/08/pdf.

Sedarmayanti, (2011). Human Resources and labor productivity, Bandung, Publisher Mandar Maju. Bandung: Mandar Maju.

Spencer, Lyle \& Signe M. Spencer. (1993). Competence at Work, Models For Superior Performance. Canada : John Wiley \& Sons, Inc.

Setiyawan, Purnomo Budhi dan Waridin. (2006). "Pengaruh Disiplin Kerja Karyawan dan Budaya Organisasi terhadap Kinerja Di Divisi Radiologi RSUP Dokter Kariadi Semarang”. Jurnal Riset Bisnis Indonesia. Vol. 2. No. 2. Juli. Hal. 181 - 198. Unissula. Semarang. http://jurnal.unissula.ac.id/index.php/jrbi/issue/view/173.

Sharma, Dilli Raj and Biswakarma, Gangaram. (2020). Mediating Role of Job Satisfaction in the Relationship Between Organizational Support and Job Performance. European Business \& Management. Volume 6, Issue 4, July 2020, Pages: 84-94. doi: 10.11648/j.ebm.20200604.13. http://article.sciencepublishinggroup.com/pdf/10.11648.j.ebm.20200604.13.pdf.

Sinambela, Lijian Poltak. (2016), Manajemen Sumber Daya Manusia Membangun Tim Kerja yang Solid untuk Meningkatkan Kinerja. Jakarta: Bumi aksara.

Sriekaningsihm, Ana and Setyadi Djoko. (2015). The Effect Of Competence And Motivation And Cultural Organization Towards Organizational Commitment And Performance On State University Lecturers In East Kalimantan Indonesia. European Journal of Business and Management

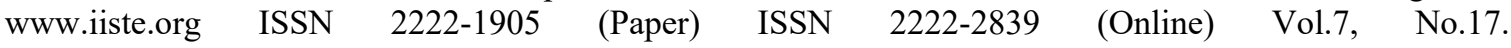
https://www.iiste.org/Journals/index.php/EJBM/article/view/23664.

Tannady, Hendy. (2018). Manajemen Sumber Daya Manusia. Yogyakarta: Expert. 